\title{
PENGEMBANGAN INSTRUMEN KETERAMPILAN MENULIS KARANGAN DAN KEMAMPUAN BERPIKIR KREATIF PADA MATERI KARANGAN NARASI SISWA KELAS IV SEKOLAH DASAR
}

\author{
Yamtinah $^{1}$, A.A.I.N. Marhaeni ${ }^{2}$, I.W. Lasmawan ${ }^{3}$ \\ ${ }^{123}$ Program Studi Pendidikan Dasar \\ Universitas Pendidikan Ganesha \\ Singaraja, Indonesia \\ e-mail: yamtinah@undiksha.ac.id ${ }^{1}$, marhaeni@undiksha.ac.id ${ }^{2}$, \\ lasmawan@undiksha.ac.id ${ }^{3}$
}

\begin{abstract}
Abstrak
Penelitian ini bertujuan untuk mengetahui: 1) validitas isi instrument keterampilan menulis karangan dan kemampuan berpikir kreatif siswa kelas IV sekolah dasar; 2) reliabilitas instrument keterampilan menulis karangan dan kemampuan berpikir kreatif siswa kelas IV sekolah dasar. Jenis penelitian ini adalah penelitian pengembangan desain dan produk (Design and Development) dengan merujuk pada model ADDIE (Analysis, Design, Development, Implementatian, Evaluation). Instrumen keterampilan menulis berupa rubric penilaian, sedangkan instrument kekampuan berpikir kreatif berupa kuisioner. Data berkaitan dengan validitas dianalisis menggunakan CVR sedangkan reliabilitas menggunakan Alpha Cronbach. Validitas diukur menggunakan uji ahli sebanyak 5 orang yang terdiri dari 2 orang dosen ahli dan 3 orang guru. Hasil penelitian menunjukkan bahwa: 1) berdasarkan perhitungan CVR, untuk validitas isi instrument keterampilan menulis tergolong valid. Untuk instrument kemampuan berpikir kreatif, dari 50 pernytaan, sebanyak 44 pernyataan dinyatakan valid dan 6 pernyataan dikatakan tidak valid. 2) Berdasarkan perhitungan, reliabilitas instrument kemampuan berpikir kreatif sebesar 0,77 yang berada pada rentang $0,60<r_{11} \leq 0,80$ atau berada pada kategori derajat reliabilitas tinggi (baik). Hasil analisis data reliabilitas kemampuan berfikir kreatif sebesar 0,74 yang berada pada rentang $0,60<r_{11} \leq 0,80$ derajat reliabilitas tinggi (baik). Berdasarkan hasil tersebut, disimpulkan bahwa penelitian ini menghasilkan instrument keterampilan menulis dan kemampuan berpikir kreatif yang valid dan reliabel.
\end{abstract}

Kata Kunci: ADDIE; Instrument Kemampuan Berpikir Kreatif; Instrument Keterampilan Menulis

\begin{abstract}
The purpose of this research is to find out : 1). The validity of the contents of instrument essay writing skills and the ability to think creatively of fourth grade elementary school student. 2). The Instrument reliability of essay writing skills and the ability to think creatively of fourth grade elementary school student. The type of research is design and product development research ( Design and Development) by using the ADDIE model (Analysis, Design, Development, Implementatian, Evaluation). The writing skill instrument is form of assessment, while the creative thinking ability instrument is form of questioner. The data related to validity were analyzed by using CVR while reliability by using Alpha Cronbach. The validity was measured by using an expert test of 5 people consisting of 2 expert lecturers and 3 teachers. The resulted of the research showed that: 1). Based on the CVR calculation, for validating the contents of the instrument writing skills are valid. For the creative thinking ability instrument, from 50 statements, 44 statements were valid and 6 statements were said to be invalid. 2). Based on calculations, the reliability of the instrument thinking ability of 0.77 which is in the range $0.60<$ rii $\leq 0.80$ or is in the category of high degree of reliability (good). The resulted of the data analysis of the reliability of creative thinking ability is 0.74 which is in the range $0.60<$ rii $\leq 0.80$ degrees high reliability (good). Based on these resulted, it was concluded that this
\end{abstract}


research produced an instrument of writing skills and creative thinking abilities that were valid and reliable.

Keywords : ADDIE; Instrument Of Think Creatively; Instrument Of Writing Skills

\section{PENDAHULUAN}

Pembelajaran adalah proses interaksi antar siswa dengan siswa, siswa dengan tenaga pendidik, dan antar siswa dengan sumber belajar pada suatu lingkungan belajar. Sedangkan proses yang dilakukan siswa secara kreatif dalam melakukan kegiatan untuk membangun pengetahuan dengan mengembangkan kreativitas secara mandiri merupakan kegiatan dalam pembelajaran.

Pembelajaran di Sekolah Dasar sudah menerapkan kurikulum 2013 yang merupakan bentuk upaya yang dilakukan pemerintah untuk mengoptimalisasi standar pendidikan nasional dalam rangka mewujudkan tujuan pendidikan nasional. Proses pembelajaran kurikulum 2013 memberikan kesempatan kepada siswa untuk mengembangkan potensinya menjadi kemampuan yang semakin lama semakin meningkat dalam sikap, pengetahuan, keterampilan, dan berperilaku langsung dalam menerima pengalaman belajarnya sehingga pembelajaran menjadi lebih bermakna. Pada penerapan kurikulum 2013, dalam proses pembelajarannya menggunakan pendekatan saintifik. Kurikulum 2013 tentang standar proses pendidikan dasar dan menengah yaitu dalam peraturan menteri pendidikan dan kebudayaan nomor 65 tahun 2013 yang lebih menekankan pada pendekatan saintifik. Pendekatan saintifik memiliki lima komponen penting yaitu mengamati, menanya, mengumpulkan informasi, menalar atau mengasosiasi, dan yang kelima adalah mengomunikasikan.

Bahasa Indonesia adalah suatu proses pembelajaran yang dibangun oleh guru untuk mengembangkan kreativitas berpikir siswa, disamping itu siswa mampu menggunakan bahasa yang benar serta mampu menikmati dan memanfaatkan karya sastra untuk mengembangkan kepribadian serta memperluas wawasan dalam berbahasa, memahami pikiran serta mampu mengungkapan gagasan atau ide yang merupakan tujuan dalam pembelajaran di sekolah dasar pada muatan bahasa Indonesia khususnya disamping itu juga bertujuan untuk meningkatkan kemampuan berbahasa, memahami pikiran, dan mengungkapkan ide atau gagasan.

Muatan mata pelajaran Bahasa Indonesia tingkat Sekolah Dasar Kurikulum 2013 yaitu: 1. Keterampilan mendengarkan lebih menekankan pada pemahaman isi materi yang disampaikan. 2. Keterampilan berbicara dimana penerapannya ditekankan pada keterampilan berbahasa yang baik dan benar serta sopan dan santun. 3 . Keterampilan membaca menekankan dalam melatih kemampuan membaca, pemahaman dalam ejaan dengan menambahkan tema dan subtema. 4. Keterampilan menulis pada kurikulum 2013 ditekankan pada kemampuan praktek menulis serta penggunaan tanda baca dengan benar.

Empat komponen keterampilan berbahasa menurut Tarigan (2013:1) yaitu 1. Keterampilan menyimak (listening skills), 2. Keterampilan berbicara (speaking skill), 3. Keterampilan membaca (reading skill), 4. Keterampilan menulis (writing skill). Keempat komponen berbahasa tersebut saling berkaitan antara komponen yang satu dengan komponen yang lain. Jadi keterampilan menulis merupakan salah satu komponen keterampilan dalam muatan Bahasa Indonesia yang harus dikuasai oleh peserta didik. "Menulis merupakan kemampuan menggunakan bahasa untuk menyatakan ide, pikiran, atau perasaan kepada orang lain dengan menggunakan bahasa tulis" (Taufina, 2016: 67).

Keterampilan menulis merupakan salah satu komponen yang harus dipelajari dan dikuasai siswa setelah menyimak, berbicara dam membaca, maka dari itu keterampilan menulis merupakan salah satu keterampilan yang harus dikuasai dan dipahami oleh peserta 
didik. Sedangkan aktivitas menulis menurut Nurgiyantoro (2013; 425) adalah suatu aktivitas dalam kegiatan menulis yang merupakan manifestasi dalam kompetensi berbahasa setelah komponen menyimak, berbicara dan membaca yang merupakan komponen yang paling akhir dan sulit. Sedangkan kemampuan menulis tidak dapat diperoleh secara otomatis tetapi perlu adanya latihan secara rutin dan terus menerus. Menurut Qostantia (2016: 258) bahwa kemampuan menulis seseorang harus diperoleh melalui pembelajaran bukan bawaan sejak lahir.

Keterampilan menulis sangat besar manfaatnya bagi kehidupan sehari-hari, sehingga keterampilan menulis tidak dapat dikuasai dengan mempelajari teori saja, tetapi keterampilan menulis akan dapat dikuasai dengan cara berlatih. Peserta didik dikatakan terampil dalam menulis jika hasil karyanya yang berupa tulisan yang berisi pengetahuan kebahasaan yang baik sehingga membuat peserta didik terampil dalam menulis sehingga dapat membantu peserta didik di dalam proses pembelajaran khususnya dalam mata pelajaran Bahasa Indonesia.

Dalam proses pembelajaran ada beberapa permasalahan yang berkaitan dengan siswa, diantaranya adalah sebagai berikut; 1) Siswa kesulitan menemukan ide pokok; 2) Siswa kurang termotivasi dalam menulis karangan; 3) Siswa kurang memiliki perhatian terhadap pembelajaran; 4) Siswa pasif dan tidak ada yang bertanya selama proses pembelajaran, 5) hasil belajar peserta didik belum optmal. 6) Dalam menuangkan gagasan/ide, perasaan, pikiran juga pendapat ke dalam bentuk karangan masih belum terbiasa dilakukan peserta didik. 7) Penggunaan huruf kapital, tanda baca dan ejaan dalam penulisan masih sering dialami siswa. 8) Peserta didik kurang termotivasi dalam mengikuti pembelajaran dikarenakan pembelajaran yang kurang menyenangkan. Untuk mengatasi permasalahan-permasalahan yang dihadapi siswa di atas tidak semudah membalikkan telapak tangan tetapi memerlukan waktu yang cukup lama serta harus meningkatkan keterampilan menulis juga harus lebih mengoptimalkan dalam berlatih menulis terutama dalam menulis karangan.

Kemampuan siswa dalam menulis karangan juga berbeda-beda, disamping itu permasalahan yang dihadapi siswa juga berbeda-beda, sehingga guru dalam menilai peserta didik dalam menulis karangan harus disesuaikan dengan kemampuan dan keterampilan menulis siswa. Dalam menulis, kemampuan berpikir kreatif juga menajdi hal yang penting. Kemampuan berpikir kreatif merupakan daya cipta yang muncul mengalir pada diri pribadi manusia, sehingga tidak mampu dibuat-buat atau dipaksa pada manusia tersebut. Dapat dikatakan kemampuan berpikir kreatif adalah sebuah passion, atau lebih sederhananya kemampuan berpikir kreatif merupakan rasa yang timbul pada diri manusia, jika kemampuan pada diri manusia berbeda maka kreativitas akan berbeda pada setiap manusia dan juga karena kemampuan berpikir kreatif adalah rasa maka ketika ada objek yang akan mempengaruhi seseorang dan kemudian si subjek tidak mempunyai kesamaan rasa maka kemampuan berpikir kreatif tidak akan muncul.

Dalam proses pembelajaran seorang pendidik harus kreatif dalam merencanakan pembelajaran agar siswa menjadi aktif dan kreatif yang pada akhirnya adalah suatu pemahaman siswa terhadap materi yang dipelajarainya. Dalam proses pembelajaran dengan melibatkan siswa dalam memilih, menyususn dan ikut berpartisipasi dalam proses pembelajaran akan menghasilkan hasil yang lebih baiak dan lebih menyenangkan, seperti yang disampaikan oleh Lindy Peters en, (2004: 11) bahwa dalam proses pembelajaran dengan melibatkan siswa dalam pembelajaran mereka akan bertanggung jawab terhadap rencana pembelajaran yang telah mereka susun.

Maka dari itu untuk mengatasi masalah penilaian guru memerlukan instrumen yang valid dan berkualitas yang berfungsi untuk mengetahui perkembangan siswa. Fungsi tersebut dapat terlaksana jika instrumen yang digunakan dalam pelajaran Bahasa Indonesia tidak hanya mencakup penilaian 
hasil saja, tetapi juga penilaian proses. Selain itu, instrumen keterampilan menulis juga harus disusun berdasarkan pada kriteria tertentu dan disesuaikan dengan kompetensi yang akan dicapai.

Dalam hal ini perlu adanya instrumen dalam pembelajaran di sekolah, namun kita harus tahu terlebih dahulu bahwa instrumen adalah alat yang digunakan untuk memperoleh atau mengumpulkan data dalam memecahkan masalah untuk mencapai tujuan. Hasil atau keputusan yang diambil tidak akan tepat jika data yang diperoleh tidak akurat. Jadi instrumen sangat berperan dan memegang penting dalam meningkatkan mutu dalam suatu pembelajaran dan berfunsi mengungkapkan fakta menjadi data. Gambaran variabel yang diteliti untuk membuktikan hipotesis dapat dilihat dari data yang diperoleh, sedangkan benar tidaknya data yang diperoleh tergantung dari baik tidaknya instrumen pengumpulan data (Nunu Nurjana: 2011).

Faktor utama atau peranan yang sangat penting untuk menentukan mutu dalam penelitian adalah instrumen karena validitas dan kualitas penelitian sangat ditentukan oleh validitas atau keakuratan data yang diperoleh disamping prosedur pengumpulan data yang ditempuh, sedangkan menurut Kothari (2004: 73) fungsi dari instrumen adalah mengungkapkan fakta yang diubah menjadi data sehingga instrumen yang akan digunakan berfungsi untuk mengungkapkan fakta yang kemudian diubah menjadi data sehingga instrumen yang digunakan memiliki kualitas yang memadai yaitu valid dan reliabel sesuai dengan fakta dan keadaan yang sebenarnya terjadi di lapangan.

Menurut Creswell (2012: 151) mengatakan bahwa instrumen adalah alat yang digunakan untuk mengukur, mengamati serta mendokumentasikan data, sedangkan Suharsisni Arikunto mengatakan bahwa instrumen adalah alat bantu yang yang digunakan untuk membantu dalam penelitian serta dalam pengumpulan data dengan tujuan agar kegiatan yang dilakukan menjadi lebih sistematis dan mudah, lain lagi pendapat menurut lbnu Hajar bahwa instrumen penelitian merupakan salah satu alat ukur yang digunakan untuk mencari dan membantu mendapatkan informasi yang berkualitas, objektif dan sebenarnya.

Di samping itu untuk mendapatkan hasil yang lebih valid maka perlu dilakukan pengembangan instrumen dengan tujuan agar instrumen yang didapat dan mempermudah dalam penelitian, sedangkan instrumen ada 2 jenis yaitu instrumen tes dan instrumen non tes. Maka dari perlu adanya pengembangan instrumen tes dan non tes agar instrumen pengukuran hasil belajar dapat memenuhi kualitas yang baik. Untuk mendapatkan hasil instrumen pengukuran hasil belajar yang berkualitas dan baik tentunya harus memperhatikan kriteria instrumen yang baik. Instrumen penelitian agar memiliki kualitas yang baik serta valid harus memperhatikan kriteria diantaranya 1 . Validitas, 2. Reliabilitas, 3. Praktikabilitas (Grnlund \& Linn, 1997: 47) Dua kriteria yaitu validitas, reliabilitas perlu mendapat perhatian yang saksama dalam pengembangan instrumen penelitian. Seorang peneliti yang tidak mengetahui validitas serta tidak mengetahui reliabilitas instrumen yang digunakan maka sedikit pada data yang diperoleh (Kerlinger, 1973: 442)

Dalam kegiatan menulis karangan jarang terdapat instrumen menulis karangan yang baik dan benar sehingga perlu dibuat pengembangan instrumen yang memiliki kualitas validitas karena instrumen atau alat ukur merupakan hal yang penting dan utama dalam menentukan mutu dan kualitas instrumen dalam penelitian yang digunakan dalam pengumpulan data dan kualitas instrumen. . Disamping itu instrumen juga berfungsi mengungkapkan fakta menjadi data, jika instrumen yang digunakan berkualitas dan valid maka data yang diperoleh akan sesuai fakta atau keadaan yang sebenarnya yang terjadi di lapangan, jika instrumen yang digunakan dalam penelitiaan tidak baik, tidak valid atau tidak berkualitas maka data yang diperoleh juga tidaka akan valid dan tidak sesuai dengan data yang diperoleh di lapangan sehingga bisa memberi kesimpulan yang salah tidak sesuai kenyataan.

Berdasarkan uraian tersebut maka dilakukan suatu penelitian pengembangan 
tentang instrumen keterampilan menulis karangan dan kemampuan berpikir kreatif pada materi karangan siswa kelas IV sekolah dasar dengan tujuan agar diperoleh instrumen keterampilan menulis karangan narasi dan berpikir kretif yang valid dan berkualitas sehingga proses pembelajaran dapat meningkat.

\section{METODE}

Jenis penelitian ini adalah penelitian pengembangan desain dan produk (Design and Development) dengan merujuk pada model ADDIE (Analysis, Design, Development, Implementatian, Evaluation). Metode penelitian ini digunakan untuk menghasilkan suatu produk. Produk yang dikembangkan melalui penelitian pengembangan ini adalah instrument keterampilan menulis dan kemampuan berpikir kreatif. Subjek dalam penelitian ini adalah dua orang dosen ahli dan tiga orang praktisi yang memvalidasi serta memberikan saran terhadap pengembangan instrument.

Penelitan ini menggunakan model pengembangan dengan model ADDIE (Analysis, Design, Development, Implementatian, Evaluation). Tahap Analysis (Analisis), peneliti menganalisis perlu tidaknya pengembangan instrumen serta menganalisis kelayakan syaratsyarat pengembangan. Tahap design atau perancangan, peneliti merancang materi yang akan dikembangkan sesuai analisis yang sudah dilakukan sebelumnya. Selanjutnya dalam tahap ini peneliti menentukan unsur-unsur yang diperlukan serta mengumpulkan referensi yang digunakan untuk mengembangkan materi dalam keterampilan menulis. Tahap development (Pengembangan) merupakan tahap realisasi produk dimana dalam tahap ini instrument akan divalidasi oleh dosen ahli dan guru dalam proses, sedangkan validator menggunakan instrumen yang sudah disusun. Saat validasi yang dilakukan validator adalah menilai validitas isi dan konstruk terhadap instrumen menulis karangan yang dikembangkan berdasarkan butir aspek kelayakan instrumen untuk menulis karangan, disamping itu juga memberi saran dan komentar yang berkaitan dengan instrumen keterampilan menulis karangan dan berpikir kreatif yang nantinya akan digunakan sebagai patokan revisi perbaikan dan penyempurnaan instrumen menulis karangan dan berpikir kreatif. Tahap Implemantition dan Evaluasi, guru melakukan penilaian keterampilan menulis dengan menggunakan instrumen yang sudah dikembangkan.

Pengumpulan data pada penelitian ini menggunakan uji dosen ahli sebanyak 2 orang dan uji praktisi sebanyak 3 orang. Data yang dikumpulkan berupa data validitas dan reliabilitas instrumen keterampilan menulis dan kemampuan berpikir kreatif. Analisis data validitas menggunakan rumus CVR. Kriteria valid tidaknya isi butir rubrik menggunakan acuan nilai minimum CVR berdasarkan jumlah panelis. Isi butir dinyatakan valid apabila memiliki CVR $\geq 0.60$. Sedangkan, reliabilitas untuk kedua instrumen ditentukan dengan rumus Alpha Cronbach. Instrumen dikatakan reliabel jika minimal reliabilitasnya tinggi atau pada interval $0,60<r_{11} \leq 0,80$.

\section{HASIL DAN PEMBAHASAN}

Penelitian yang dilakukan difokuskan pada pengembangan instrumen keterampilan menulis karangan narasi dan kemampuan berpikir kreatif. Produk instrumen keterampilan menulis karangan berupa lembar penilaian yang dilengkapi rubrik penilaian. Sedangkan pengembangan instrumen yang kedua yaitu pengembangan instrumen kemampuan berpikir kreatif dengan produk yang dikembangakan berupa kuesioner.

\section{Hasil Uji Validitas Instrumen}

Validitas adalah sejauh mana alat ukur (tes) benar-benar menggambarkan apa yang hendak diukur sedangkan validitas dalam riset sosial merupakan masalah yang sangat penting karena menyangkut ketepatan alat ukur yang digunakan. Instrumen yang tidak tepat, tidak sesuai serta tidak valid akan berakibat pula pada hasil validasi hasil riset yang sedang diteliti. Dalam tahap validasi diperlukan instrumen yang benarbenar tepat dan sesuai. Tahap validitas instrumen dilakukan dengan tujuan agar 
instrumen yang dikembangkan dapat diketahui kelayakannya serta kevalidannya berdasarkan penilaian dari ahli materi sebanyak 5 orang, yaitu 2 orang dosen jurusan pendidikan dasar yaitu Prof. Dr. A.A.I.N. Marhaeni, M.A dan Prof. Dr. I Wayan Lasmawan, M.Pd. Praktisi di bidang pendidikan sekolah dasar sebanyak 3 orang guru yaitu Erry Trisna Nurhayana, S.Pd., M.Pd., Ni Wayan Darti, S.Pd., M.Pd., dan I Komang Adi Suardita, S.Pd., M.Pd.

Kelayakan atau relevansi isi melalui analisis oleh penilaian ahli (expert judgement) atau orang yang berkompeten disebut validasi isi. Pengukuran dengan memasukan sekumpulan item yang memadai dan mewakili dengan mengungkapkan konsep yang diteliti merupakan hasil dari validitas isi atau content validity. Menurut Sekaran (2006) fungsi dari validasi isi adalah untuk mengetahui seberapa baik dimensi dan elemen sebuah konsep yang telah digambarkan. Tujuan dari validasi isi adalah untuk memastikan apakah isi dari kuesioner sudah sesuai dan relevan dengan tujuan dalam pembelajaran.

\section{Hasil Uji Validitas Instrumen Keterampilan Menulis Karangan Narasi}

Sebelum melakukan ujicoba instrumen penilaian yang dikembangkan divalidasi terlebih dahulu oleh ahli materi, dalam pelaksanaan validasi meteri dilakukan oleh dosen pembimbing yaitu dosen pasca sarjana di Undiksha yang memiliki latar belakang sesuai dengan materi yang dikembangkan. Tujuan dari validasi yang dilakukan oleh ahli materi adalah untuk mendapatkan informasi, ktirik, dan saran agar instrumen penilaian yang dikembangkan menjadi produk yang berkualitas serta valid. Hasil dari expert judgment selanjutnya dilakukan analisis untuk mendapatkan indeks rasio validitasnya dengan melakukan perhitungan Content Validity Ratio (CVR). Rubrik penskoran untuk judges menggunakan skala 3, yaitu relevan (3), kurang relevan (2), dan tidak relevan (1).

Hasil perhitungan menunjukkan sebanyak 7 soal katagori valid. Intrumen keterampilan menulis karangan narasi tidak perlu ada perbaikan lagi karena instrumen sudah sesuai dengan kisi-kisi instrumen yang dibuat sebelumnya sehingga pengujian validitas dapat dilakukan dengan mudah serta sistematis (Sugiyono, 2010). Disamping itu soal sudah dapat dikatakan valid karena sudah tepat dan dapat untuk mengukur apa yang hendak diukur. Dengan menggunakan instrumen keterampilan menulis karangan akan sangat membantu siswa juga guru dalam melaksanakan penilaian karena akan mempermudah dalam melatih menulis karangan dengan tujuan dapat meningkatkan keberhasilan siswa dalam belajar serta meningkatkan kreatifitas siswa secara optimal tentang menulis karangan. Disamping itu dengan instrumen yang valid dan berkualitas akan mempermudah dalam mempelajari, memahami, menghayati, dan mengingat dalam waktu yang relatif singkat.

\section{Hasil Uji Validitas Instrumen Berpikir Kreatif}

Hasil analisis data Validitas isi tentang kemampuan berpikir kreatif berdasarkan dari hasil validasi oleh 2 ahli dan 3 praktisi pendidikan. Hasil perhitungan menunjukkan instrumen sebanyak 44 soal valid. Sebanyak 6 soal soal dikatakan tidak valid karena tidak sesuai dengan kompetensi dasar serta indikator soal.

\section{Hasil Uji Reliabilitas Instrumen \\ Uji reliabilitas merupakan suatu} kegiatan tes yang dilakukan untuk mengukur, sedangkan reliabilitas adalah serangkaian kegiatan pengukuran atau serangkaian alat ukur yang konsisten yang digunakan untuk melakukan pengukuran berulang-ulang. Sukaji (2000) mengatakan bahwa uji reliabilitas adalah alat untuk mengukur seberapa konsistennya sasaran yang diukur. Reliabilitas dinyatakan dalam bentuk angka, biasanya sebagai koefesien. Koefisien yang tinggi berarti reliabilitas tinggi juga.

\section{Hasil Uji Reliabilitas Instrumen keterampilan Menulis Karangan Narasi}

Reliabilitas instrumen keterampilan menulis karangan narasi dilakukan berdasarkan uji ahli dan praktisi pendidikan. Hasil perhitungan reliabilitas 
instrumen keterampilan menulis karangan narasi dibandingkan dengan tabel kriteria reliabilitas. Reliabilitas instrumen yang berbentuk rating scale keterampilan menulis karangan narasi diuji dengan rumus Alpha Cronbach berbantuan Microsoft Excel. Berdasarkan hasil uji reliabilitas maka dapat disimpulkan bahwa instrumen keterampilan menulis karangan narasi memeroleh nilai 0,77 . Data ini menunjukkan reliabilitas berada pada rentang $0,60<r_{11} \leq 0,80$ atau berada pada kategori derajat reliabilitas tinggi (baik).

\section{Hasil Uji Reliabilitas Instrumen Berpikir Kreatif}

Berdasarkan dari hasil uji reliabilitas tentang instrumen berpikir kreatif maka dapat disimpulkan bahwa hasil intrumen berpikir kreatif adalah 0,74. Data ini menunjukkan reliabilitas berada pada rentang $0,60<r_{11} \leq 0,80$ atau berada pada kategori derajat reliabilitas tinggi (baik).

Penelitian pengembangan (Reseach and Development) yang dilakukan peneliti bertujuan untuk menghasilkan instrumen pembelajaran tentang keterampilan menulis karangan dan intrumen tentang daya kreatif dengan materi pembelajaran keterampilan menulis karangan narasi dalam muatan Bahasa Indonesia kelas IV Sekolah Dasar. Instrumen yang dikembangkan dinyatakan layak dan valid digunakan berdasarkan validitas oleh ahli. Desain penelitian pengembangan (Research and Development) ini mengacu pada model pengembangan dari Borg and Gall. Dalam penelitian ini prosedur pengembangan yang digunakan oleh peneliti adalah ADDIE. Adapaun tahapan pengembangan yang dilakukan disajikan sebagai berikut.

Pertama, Analysis (Analisis). Peneliti menganalisis perlu tidaknya pengembangan instrumen serta menganalisis kelayakan syarat-syarat pengembangan yang akan dilakukan yang merupakan tahapan dalam analisis. Analisis memiliki tiga tahapan yang harus dilakukan oleh peneliti, tiga hal tersebut adalah analisis kebutuhan, analisis kurikulum serta analisis karakter peserta didik. Tahap analisis kebutuhan, peneliti menganalisis bahan ajar sebagai faktor utama atau sebagai informasi utama dalam pembelajaran serta tersedianya bahan ajar yang mendukung terlaksananya suatu pembelajaran sehingga perlu ditentukan juga bahan ajar yang akan dikembangkan untuk membantu peserta didik dalam belajar. Tahap analisis kurikulum, peneliti melakukan analisis dengan memperhatikan karakteristik kurikulum yang digunakan saat itu pada sekolah tersebut dengan tujuan agar pengembangan yang dilakukan sesuai tuntutan kurikulum yang berlaku saat itu yaitu kurikulum 2013, selanjuytnya peneliti mengkaji Kopetensi Dasar (KD) untuk merumuskan indikator-indikator yang akan dicapai dalam pembelajaran. Tahap analisis karakter peserta didik, peneliti melihat sikap peserta didik terhadap pembelajaran bahasa Indonesia, hal ini dilakukan dengan tujuan agar pengembangan yang dilakukan sudah sesuai dengan karakter peserta didik.

Kedua, Design (perancangan). Tahap design atau perancangan merupakan tahap kedua dalam pengembangan model ADDIE. Dalam tahap ini peneliti merancang materi yang akan dikembangkan sesuai analisis yang sudah dilakukan sebelumnya. Selanjutnya dalam tahap ini peneliti menentukan unsur-unsur yang diperlukan serta mengumpulkan referensi yang digunakan untuk mengembangkan materi dalam keterampilan menulis. Tahap selanjutnya peneliti menyusun instrumen yang akan digunakan untuk menilai keterampilan menulis karangan dengan memperhatikan aspek yang dinilai dalam menulis karangan tersebut diantaranya adalah dengan menggunakan rubrik penelitian dengan memperhatikan aspek karangan naratif yaitu: 1) Kesesuaian isi karangan dengan topik (tema), 2) Penokohan dan Perwatakan, 3) Latar dan amanat, 4) Pilihan kata (diksi), 4) Penggunaan ejaan dan tanda baca, dan 5) Alur cerita. Langkah selanjutnya adalah memvalidasi instrumen yang sudah disusun dengan tujuan untuk mendapatkan instrumen penilaian yang valid.

Ketiga,

Development

(Pengembangan). Tahap ini merupakan tahap pengembangan menulis karangan yang dilakukan sesuai rancangan yang 
sudah disusun, dalam tahap pengembangan ini merupakan tahap realisasi produk dimana dalam tahap pengembangan ini instrumen dosen ahli akan menvalidasi bersama guru praktisis dalam pendidikan, sedangkan instrumen yang sudah disusun akan digunakan oleh validator. Saat validasi yang dilakukan validator adalah menilai validitas isi dan konstruk terhadap instrumen menulis karangan yang dikembangkan berdasarkan butir aspek kelayakan instrumen untuk menulis karangan, disamping itu juga memberi saran dan komentar yang berkaitan dengan instrument keterampilan menulis karangan dan berpikir kreatif yang nantinya akan digunakan sebagai patokan revisi perbaikan dan penyempurnaan instrumen menulis karangan narasi dan kemampuan berpikir kreatif. Hasil perhitungan validitas dari instrumen keterampilan menulis karangan narasi dengan jumlah butir soal sebanyak 7 dan semua tergolong valid. Sedangkan nilai reliabilitas sebesar 0,77 yang berada pada rentang $0,60<r_{11} \leq$ 0,80 atau berada pada kategori derajat reliabilitas tinggi (baik). Instrumen kemampuan berpikir kreatif instrumen sebanyak 50 pernyataan , untuk pernyataan yang tidak valid sebanyak 6 soal yaitu nomor 4, 27, 32, 39, 44, dan 50 . Instrumen yang valid sebanyak 44 soal yaitu nomor $1,2,3,5,6,7,8,9,10,11$, $12,13,14,15,16,17,18,19,20,21,22$, $23,24,25,26,28,29,30,31,33,34,35$, $36,37,38,40,41,42,43,45,46,47,48$, dan 49. Soal dikatakan tidak valid karena tidak sesuai dengan kompetensi dasar serta indikator soal. Hasil analisis data reliabilitas kemampuan berpikir kreatif sebesar 0,74 yang berada pada rentang $0,60<r_{11} \leq 0,80$ derajat reliabilitas tinggi (baik).

Keempat, implementasi. Dalam tahap ini guru melakukan penilaian keterampilan menulis dengan menggunakan instrument yang sudah dikembangkan. Tahap evaluasi merupakan tahap dimana peneliti melakukan revisi terakhir terhadap instrumen yang dikembangkan berdasarkan masukan yang didapat dari angket respon pada lembar observasi yang diperoleh dengan tujuan agar instrumen menulis karangan yang sudah dikembangkan benar-benar sesuai, valid serta berkualitas dan dapat digunakan oleh sekolah secara luas. Dalam penelitian ini, tahap implementasi dan evaluasi tidak dapat dilaksanakan karena kondisi lapangan dalam keadaan pandemic CoVid-19, sehingga penelitian ini hanya terbatas pada tahap development (pengembangan).

\section{PENUTUP}

Secara umum penelitian ini dapat disimpulkan bahwa tahapan pengembangan instrumen menggunakan model ADDIE meliputi tahap analisys, design, development, implementatiton dan evaluation. Untuk tahapan implementation dan evaluation tidak dapat dilaksanakan akibat adanya pandemic CoVid-19 yang mengharuskan siswa maupun guru untuk menerapkan work from home. Pembelajaran dilakukan secara daring, sehingga instrumen yang dikembangkan terbatas pada uji validitas ahli.

Penelitian pengembangan ini menghasilkan instrumen keterampilan menulis karangan narasi sebanyak 7 butir. Selanjutnya dilakukan analisis uji validitas isi untuk instrumen keterampilan menulis karangan narasi pada siswa kelas IV SD menggunakan CVR. Berdasarkan hasil perhitungan CVR sebanyak 7 dan semua tergolong valid. Sedangkan nilai reliabilitas sebesar 0,77 yang berada pada rentang $0,60<r_{11} \leq 0,80$ atau berada pada kategori derajat reliabilitas tinggi (baik).

Instrumen kedua yaitu kemampuan berpikir kreatif dengan mengembangkan kuesioner berjumlah 50 pernyataan. Berdasarkan hasil dari perhitungan CVR, pernyataan yang tidak valid sebanyak 6 soal, instrumen yang valid sebanyak 44 soal. Hasil analisis data reliabilitas kemampuan berfikir kreatif sebesar 0,74 yang berada pada rentang $0,60<r_{11} \leq$ 0,80 derajat reliabilitas tinggi (baik).

Instrumen penilaian tidak harus didapat dengan cara mencontek orang lain tetapi guru dapat lebih berkreatif dengan membuat atau menyusun interumen penilaian sendiri, maka dari itu seorang guru dituntun untuk mengali potensi diri, lebih kreatif dan berinovatif untuk 
menciptakan hal-hal yang baru terutama dalam instrumen penilaian.

Dengan penulisan pengembangan instrumen penilai keterampilan menulis karangan dan instrumen penilaian sikap berpikir kreatif bisa membuka cakrawala bagi pendidik untuk dapat membuat intrumen penilaian yang lebih bervariatif untuk meningkatkan kualitas serta instrumen yang lebih valid, serta mempermudah pendidik dalam menilai sehingga akan meningkatkan pembelajaran disamping itu indikator dapat pembelajaran dapat tercapai seperti yang diharapkan dalam kurikulum 2013.

Hasil penelitian pengembangan diharapkan dapat memotivasi agar kita selalu berkarya dan berinovasi di bidang pendidikan terutama di lingkungan sendiri juga memotivasi kepada pendidik lainnya agar lebih termotivasi untuk berkarya. Bisa juga dijadikan referensi bagi guru untuk berbuat dan menciptakan hal yang baru.

\section{DAFTAR RUJUKAN}

Agung, A. A. G. 2014. Buku Ajar Metodologi Penelitian Pendidikan. Yogyakarta: Aditya Media Publishing.

Anderson. L.W\&David. Krathwohl. 2010. Terjemahan. Kerangka Landasan Untuk Pembelajaran, Pengajaran dan Asesmen. Revisi Taksonomi Bloom. Yogyakarta: Putaka Pelajar

Arikunto, S. 2013. Prosedur Penelitian Suatu Pendekatan Praktik. Jakarta: PT Rineka Cipta.

Arikunto, Suharsimi. 2003. Manajemen Penelitian. Jakarta: Rineka Cipta

Arikunto, Suharsimi. 2006. Prosedur Penelitian Suatu Pendekatan Pratik. Jakarta: Rineka Cipta

Arikunto, Suharsimi. 2015. Dasar-Dasar Evaluasi Pendidikan Edisi 2. Jakarta: PT Bumi Aksara

Asmin. 2006. Pengaruh Ragam Bentuk Tes Objektif dan Gaya Berpikir terhadap Fungsi Informasi Tes: Penelitian Quasi Eksperimental dengan Analisis Item Response Theory di SMU DKI Jakarta. Jurnal Pendidikan dan Kebudayaan. 062 (12):633—655.
Borg, W.R. \& Gall, M. D. (2003). Educational Research: An Introduction. Boston: Pearson Education Inc.

Candiasa, I.M. 2010, Pengujian Instrumen Penelitian disertai Aplikasi ITEMAN dan BIGSTEP. Singaraja: Undiksha Pres

Coon, D. \& Mitterer, J.O. 2014. Psychology; A Journey. Fifth Edition. California: Wadsworth, Cengage learning.

Dalman. 2014. Keterampilan Menulis. Jakarta: Rajawali Press

Dantes, N. 2017. Desain Eksperimen dan Analisis Data. Depok: Raja Grafindo Persada.

Dantes, N. 2017. Pedagogik dalam Perspektif. Singaraja: Undiksha Press.

Dantes, Nyoman 2012. Metode Penelitian. Yogyakarta : Penerbit Andi Offset.

Darmani, N.N., Marhaeni, A.A.I.N., \& Sutama, I. M. 2013. Pengaruh Strategi Pemodelan Berbantuan Media Cetak Terhadap Kemampuan Mengarang Prosa Siswa Kelas V SD Ditinjau Dari Bakat Verbal. Jurnal Pendididkan Dasar Pascasarjana Universitas Pendidikan Ganesha.

Depdiknas, 2006. Kurikulum Tahun 2006. Kurikulum Tingkat Satuan Pendidikan Jakarta: Depdiknas.

Drapeau, P. 2014. Sparking Student Creativity: pratical ways to promote Innovative Thinking and Problem Solving. Virginia: ASCD

Dunn, W.N. (2008). Public Policy Analysis: An Introduction. Englewood Cliff, N.J.: Prectice Hall, Inc.

Endrayanto, Sunu dan Wahyu Harumurti. 2017. Aplikasi Rubrik untuk Penilaian Belajar Siswa Menilai Tanpa Menghakimi. Yogyakarta: PT Kanisius.

Fraenkel, J.C., Wallen, N.E., Hyun, H.H., (2012). How to Design and Evaluate Research in Education, New York: Mc Graw Hill. 
Gina, A M. 2017. Meningkatkan Keterampilan Menulis Karangan Narasi Melalui Model Pwim (Picture Word Inductive Model) Siswa Kelas IV B SD Negeri Ketib Kecamatan Sumedang Utara Kabupaten Sumedang. Tersedia pada Jurnal Pena IImiah: Vol.2, No1 (2017) 141

Guilford.1973. Fundamental Statistics in Psychology and Education. Third Edition. Tokyo: Kogakusha Company Ltd.

Hernawan, A.H. dkk. (2007). Belajar dan pembelajaran di Sekolah Dasar. Bandung: UPI PRESS.

Hosnan, M. 2014. Pendekatan Saintifik dan Kontekstual dalam Pembelajaran Abad 21: Kunci Sukses Implementasi Kurikulum 2013. Jakarta. Ghalia Indonesia

Indihadi, D. dkk. (2009). Pembinaan bahasa Indonesia sebagai bahasa kedua. Bandung: UPI PRESS.

Kementrian Pendidikan dan Kebudayaan. 2016. Direktorat Jendral Pendidikan Dasar dan Menengah. Panduan Teknis Pembelajaran dan Penilaian di Sekolah dasar. Jakarta: Direktorat Pembinaan Sekolah Dasar.

Kementrian Pendidikan dan Kebudayaan. 2016. Permendikbud No. 21 Tahun 2016 tentang Standar Isi Pendidikan Dasar dan Menengah. Jakarta: Departemen Pendidikan dan Kebudayaan.

Kementrian Pendidikan dan Kebudayaan. 2016. Permendikbud No. 23 Tahun 2016 tentang Standar Penilaian Pendidikan Pada Kurikulum 2013 Pada Pendidikan Dasar dan Menengah. Jakarta: Departemen Pendidikan dan Kebudayaan.

Kementrian Pendidikan dan Kebudayaan. 2016. Permendikbud No. 24 Tahun 2016 tentang Kompetensi Inti dan Kompetensi Dasar Pelajaran Pada Kurikulum 2013 Pada Pendidikan Dasar dan Menengah. Jakarta: Departemen Pendidikan dan Kebudayaan.
Khori, N. dkk. 2017. Teaching creative Thinking Skill with Laboratory Work. Internasional Journal of Science and Applied Science: Conference Series P-ISSN: 2549-4635 E-ISSN: 25494627 Int. J. Sci. Appl. Sci. Conf. Ser. Vol.2 No. 1. https://jurnal.uns.ac.id/ijsascs/article/ view/16722/13506.

M. David Miller, Linn \& Gronlund, 2012. Measurement and Assessment in teaching. Texas: Pearson.

McMillan, J.H. \& Schumacher, S. (2001). Research in Education: A Conceptual Introduction. New York: Addison Wesley Longman, Inc.

Mulyati. 2015. Terampil Berbahasa Indonesia untuk Perguruan Tinggi. Jakarta: Prenamedia Group.

Munandar, U.2012. Pengembangan Kreativitas Anak Berbakat. Jakarta: Rineka Cipta

Nilayanti, PM. 2019. Pengaruh Model Pembelajaran Talking Stick terhadap Kemampuan Berpikir Kreatif dan Literasi Sains Siswa Kelas IV SD. Tersedia pada Jurnal Pendasi Vol. 3 No. 1 Pebruari 2019

Nurgiantoro, Burhan. 2016. Penilaian Pembelajaran Bahasa Berbasis Kompetensi Yogyakarta: BPFE Yogyakarta.

Permendikbud Nomor 54 Tahun 2013 tentang Standar Kompetensi Lulusan Jakarta: Departemen Pendidikan dan Kebudayaan.

Permendikbud Nomor 66 Tahun 2013 yang berisi tentang standar penilaian pendidikan pada jenjang pendidikan dasar dan menengah. Jakarta: Departemen Pendidikan dan Kebudayaan.

Ratumanan, T.G. 2003. Pengaruh Model Pembelajaran Dan Gaya Kognitif Terhadap Hasil Belajar Matematika Siswa SLTP Di Kota Ambon. Jurnal Pendidikan Dasar, vol. 5 (1): 1-10.

Resmini, N. dkk. (2009). Pembinaan dan pengembangan pembelajaran 
bahasa dan sastra Indonesia. Bandung: UPI PRESS.

Richards, \& Rodgers. 1986. Approaches and Method in Language Teaching. United States: Cambridge University Press.

Siddik, Mohammad. 2018. Peningkatan Pembelajaran menulis Karangan Narasi melalui Gambar Berseri Siswa Sekolah Dasar. Jurnal Sekolah Dasar: Kajian Teori dan Praktik Pendidikan dari http://journal2.um.ac.id/index.php/sd// SSN 0854-8285 diakses pada 10 Juli 2020

Slamet. 2014. Pembelajaran Keterampilan Berbahasa Indonesia Teori dan Aplikasi. Yogyakarta: Graha IImu.

Starko, A.J. 2010. Creativity in the Classroom: Schools of Curious Delight. New York: Routledge.

Sudijono, A. 2011. Pengantar Evaluasi Pedidikan. Jakarta: Raja Grafindo Persada.

Sugiyono. 2013. Metode Penelitian Pendidikan Pendekatan Kuantitatif, Kualitatif dan R\&D. Bandung: Alfabeta

Sugiyono. 2015. Metode Penelitian \& Pengembangan. Bandung: Alfabeta.

Sugiyono. 2015. Metode Penelitian Pendidikan Pendekatan Kuantitatif, Kualitatif dan $R \& D$. Bandung: Alfabeta

Sugiyono. 2017. Statistika untuk Penelitian. Bandung: Alfabeta.

Sukardi.2012. Metodelogi Penelitian Pendidikan. Jakarta: PT. Bumi Aksara

Supardi. 2015. Penilaian Autentik. Jakarta: Raja Grafindo Persada

Tarigan, Henry Guntur. 2013. Menulis Sebagai Suatu Keterampilan Berbahasa. Bandung: CV. Angkasa.

Taufina. Faisal. 2016. Mozaik Penilaian Pembelajaran Bahasa dan Apresiasi
Sastra Indonesia di Sekolah Dasar. Bandung: CV. Angkasa.

Tompkins, G.E., \& Hoskisson, K. 2010. Languange Art Ciontent and teaching Strategies. New York: Macmillan.

Trianto. 2007. Model Pembelajaran Terpadu dalam Teori dan Praktek. Surabaya: Prestasi Belajar

Yuliani, Hadma. 2017. Keterampilan berpiki Kreatif Pada Siswa Sekolah Menengah di Palangkaraya Menggunakan Pendekatan Saintifik. Palangkaraya: Institut Agama Islam Negeri Palangkaraya. Jurnal Pendidikan Fisika dan Keilmuan (JPFK). Vol. 3 